\title{
INADEQUATE INTAKE OF POLYUNSATURATED FATTY ACIDS DURING PREGNANCY AND LACTATION, AND ITS ASSOCIATION WITH INFANT COGNITIVE DEVELOPMENT
}

\author{
Noer laily'), Kusharisupeni'), Ratna Juwita²), Purwantyastuti3), \\ Soedjatmiko3), Diah Mulyawati Utari'2), Soeminarti Padmonodewo4), \\ Suyanto Pawiroharsono5) \\ 1) Center for Agroindustrial Technology-BPPT, Jakarta \\ 2)Faculty of Public Health, Universitas Indonesia \\ 3) Faculty of Medicine, Universitas Indonesia \\ 4)Faculty of Psychology, Unversitas Indonesia \\ 5)Center for Bioindustrial Technology-BPPT, Jakarta
}

\begin{abstract}
Background: Cognitive development in early childhood is an important predictor of intelectual capacity in later life. Individuals who are markedly late in achieving developmental milestones are at high risk for a subsequent diagnosis of learning disability/mental retardation. There is considerable interest in the role of certain long chain polyunsaturated fatty acids (LCPUFA), in visual and cognitive development throughout childhood. Omega-3 long chain polyunsaturated fatty acids (n-3 LCPUFA) are important constituents of the maturing brain and therefore considered crucial for brain development in utero and in early infancy. The n-3 fatty acid docosahexaenoic acid (DHA) and the n-6 fatty acid arachidonic acid (AA) are the major LCPUFA in the brain. This study aimed to examine the inadequate intake of PUFA during pregnancy and lactation, and its association with infant cognitive development.
\end{abstract}

Subjects and Method: This was acohort study conducted in Pandeglang, Banten. A total of 102third trimester pregnant motherswere selected for this study and followed until 4 months after child birth. The dependent variable was infant cognitive development. The independent variables were emotional and verbal environmental stimuli, maternal nutrition omega 3 intake. Data on maternal nutrition intake during pregnancy were measured by 24 hour recall and food frequency questionnaire (FFQ). The other data were collected by questionnaire. The data were analyzed by a multiple logistic regression.

Results:Good infant cognitive development increased with adequate emotional and verbal environmental stimuli $(\mathrm{OR}=7.52 ; 95 \% \mathrm{CI}=1.80$ to $31.35 ; \mathrm{p}=0.006)$ and adequate maternal nutrition omega 3 intake $(\mathrm{OR}=5.65 ; 95 \% \mathrm{CI}=1.45$ to 21.99; $\mathrm{p}=0.013$ ).

Conclusion:Good infant cognitive development is determined by not only adequate maternal nutrition omega 3 intake, but also good emotional and verbal environmental stimuli.

Keywords: cognitive development, maternal nutrition intake, polyunsaturated fatty acids, omega 3 , infant.

\section{Correspondence:}

Noer laily. Center for Agroindustrial Technology-BPPT, Jakarta, Indonesia.

Email: noerlaily2015@gmail.com. Mobile:08128030931. 